\title{
THE QUOKKA
}

The first bulletin on fauna conservation in Western Australia, published in 1956, contains an article by Mr. A. R. Main, of the University of Western Australia, on the importance of pure research in conservation. In developing his theme, Mr. Main tells of investigations into the natural history of a small wallaby, Setonix brachyurus, the quokka.

This little marsupial was once abundant in the south-west of Western Australia but is now virtually extinct except on Rottnest Island off Fremantle. Its digestion has been found to be ruminant-like, as in a sheep or cow rather than a horse. In this particular type of digestion the animal feeds the bacterial flora of its stomach. These break down otherwise indigestible substances, such as cellulose, and the ruminant gets it nutritional requirements by digesting the bacteria, and by absorbing the fatty acids which are the waste products of their metabolism.

The continued existence of the quokka even on Rottnest is itself something of a mystery, for in midsummer there is no apparent source of fresh drinking water. Experiments show that quokkas are unable to satisfy their water requirements either by water of metabolism or with sea water, though some could utilize $2 \frac{1}{2}$ per cent saline for a limited period. Some quokkas regularly visit shallow seepages around salt lakes, others may obtain enough water from succulents ; nevertheless others seem to survive without either fresh water or succulents. How, is not known.

The investigations of Dr. G. A. Bartholomew into the heat regulating mechanisms of marsupials reveal that in hot weather the quokka remains cool by salivating over its fore-limbs and the front of its body. This may adversely affect its survival if, as seems certain, the woodlands on Rottnest are decreasing. For, in the absence of decp, cool shade, not only may direct heating be excessive but the animal may not be able to spare the liquid necessary for cooling. Moreover, in salivating some of the ions used to maintain the acidity of the stomach are lost. It may then not be possible for the bacteria to break down the cellulose and the quokka's nutrition will suffer. 